\title{
Impact of frequency of milking on milk yield and fertility of Holstein cows undergoing extended lactations due to failure to conceive
}

\author{
Jesús Mellado', Jessica Flores², Francisco G. Véliz², Ángeles de Santiago², José E. García1, \\ Hugo L. Gutierrez', Miguel Mellado"* \\ ${ }^{1}$ Autonomous Agrarian University Antonio Narro, Department of Animal Nutrition, Saltillo, Mexico, ${ }^{2}$ Autonomous Agrarian University Antonio \\ Narro, Department of Veterinary Science, Torreon, Mexico
}

\section{A B S T R A C T}

\begin{abstract}
The objective of this observational study was to determine the effect of two $(2 x)$ compared to three $(3 x)$ times a day milking in Holstein cows undergoing lactations $\geq 600 \mathrm{~d}$ on milk production and reproductive performance. Two large adjacent commercial dairy herds with similar size, facilities, and management in a hot area of northern Mexico $\left(25^{\circ} \mathrm{N}\right)$ were used. Cows in one herd $(\mathrm{n}=214)$ were milked two times a day $(2 x)$, the other herd was milked three times a day $(3 x ; n=245)$ and both groups were milked for at least 600 days. For cows in first lactation, total milk yield did not differ between $3 x$ and $2 x$ cows $(19796 \pm 3354 \mathrm{vs} .19269 \pm 3652 \mathrm{~kg} ; p>0.10)$ in lactations with an average of 696 and 650 days in milk (DIM), respectively. Multiparous $3 x$ cows produced more total milk days than $2 x$ cows $(20942 \pm 3920$ vs. $18910 \pm 2632 \mathrm{~kg} ; p<0.01)$ with greater $(p<0.01)$ DIM for $3 x(685 \pm 117$ days) than $2 x(631 \pm 88$ days) cows. Lactation persistence was greater $(p<0.05)$ in $2 x(62 \pm 9 \%)$ than $3 \times(60 \pm 10 \%)$ cows. Overall conception rate (CR) did not differ between $2 x$ and $3 x$ cows $(53.3 \%$ vs. $49.8 \%)$ but $3 x$ cows required one more service $(p<0.01)$ to get pregnant than $2 x$ animals. Given that average milk yield throughout the complete lactation did not differ between $2 \times(29.8 \pm 2.0 \mathrm{~kg})$ and $3 \times(29.3 \pm$ $2.9 \mathrm{~kg}$ ) cows, it was concluded that two-times-a-day milking is equally effective as three-times-a-day milking to attain acceptable milk yield in lactations over 600 days. However, reproductive performance based on first-service CR and services per pregnancy was negatively affected by three-times-a-day milking.
\end{abstract}

Keywords: Conception rate; Dairy cattle; Extended lactations; Heat stress; Lactation length

\section{INTRODUCTION}

In temperate zones with limited impact of heat stress, a 305-d lactation is considered an optimum lactation length. However, in zones where dairy cows undergo thermal stress for most of the year, heat stress negatively impacts the ability of a cow to become pregnant before 100 days postcalving and this infertility leads to involuntary extended lactations (Mellado et al., 2016).

In Australia and New Zealand the potential role of extended lactations with a 24-mo calving interval on pasture-based systems has been studied (Auldist et al., 2007; Kolver et al., 2007). This management practice is the result of the marked transformation that the modern dairy cow had gone through during the past decades. These effects included reproductive failure derived from the steady and continued selection for increased milk yield (Walsh et al., 2011; Berry et al., 2016), and today it is not uncommon for cows to be dried off with very high milk yields (Lehmann et al., 2017; Rajala-Schultz et al., 2018).

Drawbacks of extended lactations are alteration of herd composition as it results in fewer calvings per year, and hence fewer replacement calves, heifers, and dry cows if the number of lactating cows is maintained for prolonged periods of lactation. This may reduce herd feed use, and it thereby should increase the forage to concentrate ratio because cows will spend a greater period of the year on the downward slope of the lactation curve. Additionally, cows with extended calving intervals have longer periods in late lactation, which leads to a greater partitioning of nutrients away from the udder and toward body energy reserves (Marett et al., 2015).

\footnotetext{
${ }^{*}$ Corresponding author:

Miguel Mellado, Autonomous Agrarian University Antonio Narro, Department of Animal Nutrition. E-mail: melladomiguel07@gmail.com

Received: 19 October 2020; $\quad$ Accepted: 12 February 2021
} 
On the other hand, advantages of extended lactations are fewer calvings per cow per year which reduces the number of dry days per cow per year and results in lower incidences of periparturient diseases, and hence fewer parturitions per cow per year should improve animal health, which would improve longevity of cows (Sehested et al., 2019). Additionally, extended lactations of high-yielding cows could have economic advantages (Lehmann et al., 2019) and allows the farmer to decide the fate of individual cows (Rodríguez-Godina et al., 2021).

Total milk yield can be stimulated by increasing milking frequency (Wall and McFadden, 2012). This effect has been attributed to a protein feedback inhibitor of lactation (FIL) (Weaver and Hernandez, 2016) or serotonin (Hernandez et al., 2011) in milk, which seems to act via a negative feedback mechanism on the udder secretory cells; thus, their removal from the mammary tissue allows additional milk synthesis. Additionally, change in milking frequency affects proliferation of mammary cells as well as expression of the major milk protein genes, which both contribute to the observed changes in milk yield (Murney et al., 2015). Some studies in cows have shown no response in milk production to thrice daily milking (McNamara et al., 2008), but other studies have shown a steady increase of milk yield with increased milking frequency (Vijayakumar et al., 2017). It is not quite clear if three times a day milking is strictly necessary to maintain a greater milk persistency, and therefore to reach economically viable lactations over 600 days. Therefore, this observational study aimed to analyze the effect of the frequency of milking (two vs. three milkings a day) on the reproductive performance and milk yield in high-producing dairy cows whose lactation length was over 600 days.

\section{MATERIAL AND METHODS}

\section{Study herds}

Milk yield and reproductive performance records for 2016 and 2018 were obtained from two adjacent large intensive dairy herds ( $>2500$ milking cows) in northern Mexico. Cows suffered hyperthermia for most of the year which caused that many cows got pregnant $>300$ days postpartum, which led to extended lactations $(669 \pm 117$ days for cows included in the present study; mean $\pm \mathrm{SD})$.

Herds were selected based on good milk and reproductive record-keeping (Afifarm; Kibbutz Afikim, Israel), high closeness between them (similar climatic conditions), fairly similar nutritional health and management programs (both herds belonged to the same company; Fig. 1). In one of the farms, cows were subjected to two-times-a-day milking (2x) whereas in the other farm cows were milked

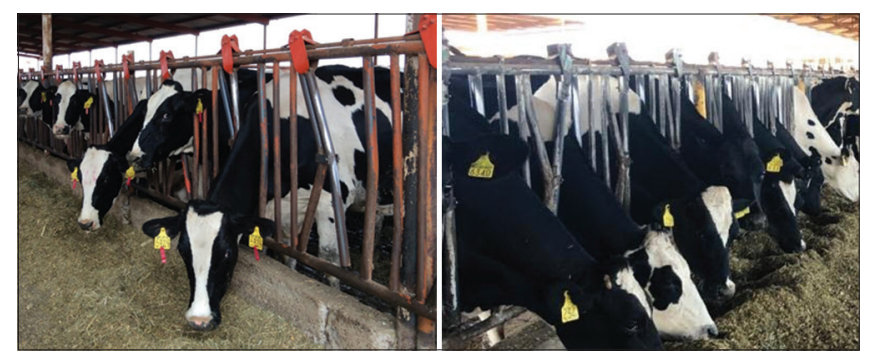

Fig 1. Cows with lactation length $\geq 600$ days enrolled in this. Cows on the left were milked two times a day; cows on the right were milked three times a day.

three times a day $(3 \mathrm{x})$. These dairy farms are located in northern Mexico $\left(25^{\circ} \mathrm{N}\right)$ in a zone characterized by high daytime temperatures in spring, summer, and fall (around $40^{\circ} \mathrm{C}$ ) and intense solar radiation with an average annual precipitation of $230 \mathrm{~mm}$.

\section{Cows facilities and feeding}

Cows were kept in open dirt pens with plenty of shade equipped with fans in both barns. Cows were fed the same total mixed ration diet thrice daily. Diet was formulated to meet the nutrient requirements for Holstein cows weighing $650 \mathrm{~kg}$ and producing $45 \mathrm{~kg}$ of $3.5 \%$ fat-corrected milk (NRC, 2001). The forage: concentrate ratio was 50:50 and diets consisted of the following primary ingredients on a DM basis: alfalfa hay, corn silage, soybean meal, corn grain, cottonseed meal, and a mineral premix.

\section{Reproductive management and variables}

Cows in both dairies received vaccines against the major cause of abortion. The herd veterinarians examined fresh cows to detect and treat cows with postpartum reproductive disorders as well as ketosis (urine ketone evaluation with Ketostix; Bayer Corp. Diagnostics Division, Elkhart, IN).

Cows were enrolled in fixed-time artificial insemination receiving two injections of $\mathrm{PGF}_{2} \alpha$ (Lutalyse, Zoetis Animal Health, NJ) at $54 \pm 2$ and $68 \pm 2$ days in milk (DIM). They were subsequently submitted to the Ovsynch protocol: $100 \mu \mathrm{g}$ GnRH (Cystorelin, Merial Ltd, NJ) at $81 \pm 3$ DIM, $\mathrm{PGF}_{2} \alpha$ at $88 \pm 3 \mathrm{DIM}$, and $\mathrm{GnRH}$ at $90 \pm 3$ DIM, and then inseminated at fixed time at $90 \pm 2$ DIM.

Cows not pregnant with the first service were observed for estrus detection aided by tail chalk which was applied daily. Cows in estrus were artificially inseminated with frozen/ thawed semen from multiple USA Holstein sires. Artificial insemination (AI) following the AM-PM guideline.

Due to severe heat stress, the majority of cows continued to be inseminated beyond 250 DIM; the range for number of services was 1-15 for $2 x$ cows and 1-22 for $3 x$ cows. Pregnancy diagnoses were performed at $45 \pm 3$ days from 
their last AI. Reproductive performance was monitored at a herd-level based on first service conception rate (CR), overall CR, services per conception (SC; only pregnant cows). First service CR was defined as the number of cows that were pregnant to their first AI divided by the total number of cows for which a first service date was recorded after calving. CR to all services was defined as the number of cows that became pregnant up to 500 DIM divided by the number of cows inseminated throughout their lactation. SC was defined as total AI to pregnant cows divided by total pregnant cows.

\section{Milk recording}

All cows were between first and five lactations and were selected based on 1) lactation not starting with an abortion, 2) cows not induced hormonally into lactation; 3) four functional quarters; 4) at least 600 DIM, 5) good general health, and 6) without ovarian or uterine disorders after calving. Cows at both dairies were machine milked two $(0500$ and $1700 \mathrm{~h})$ or three times a day $(0000,0800$, and $1600 \mathrm{~h}$ ), and yields were recorded electronically at each milking for all cows and were used to calculate 305-d milk yield and total milk yield.

Cows were dried off $60 \mathrm{~d}$ before their expected parturition date, or when daily milk yield was $\leq 20 \mathrm{~kg}$. Cows were categorized as primiparous (parity one) and multiparous (parity $\geq$ two). Outcome variables were 305 -d milk yield, daily milk yield up to 305 days postpartum, DIM, average daily milk yield during the entire lactation, and 305-d lactation milk yield persistence [305-d milk yield/(peak milk yield x 305) x 100].

\section{Statistical analyses}

Descriptive statistics of these observational data were obtained with the FREQ procedure of SAS (SAS Inst. Inc., Cary, NC). Conception data were analyzed using the GENMOD procedure of SAS. The model statement for these dependent variables contained only the effect of treatment (number of milkings per day); month of parturition was included as covariate. After limiting the number of SC to cows with a confirmed gestation diagnosis, the effect of treatment on the number of SC was evaluated by the bivariate Wilcoxon rank-sum test (proc npar1way of SAS) without adjustment for confounders. For all analyses, significance was set at $p<0.05$.

Data on milk yield as well as various reproductive intervals were analyzed according to a completely randomized design using the PROC MIXED procedure of SAS. The general model used was $Y_{i j}=\mu+A_{i}+e_{i j}$, where $Y_{i j}$ is the dependent variable, $\mu$ is the overall mean, $A_{i}$ is the effect of the ith treatment (number of milkings per day) and $\mathrm{e}_{\mathrm{ij}}$ is the random residual error. Non-linear functions were used to describe the association between DIM and total milk yield (CurveExpert Professional 2.5.6; Hyams Development, Huntsville, Alabama).

\section{RESULTS}

Milk production traits are shown in Table 1. Lactation length was 50 days longer $(p<0.01)$ in $3 x$ cows than $2 x$ cows. Parity did not influence this trait. Regardless of parity, increasing milking frequency from $2 \mathrm{x}$ to $3 \mathrm{x}$ raised $305-\mathrm{d}$ milk production by $648 \mathrm{~kg}(6 \% ; p<0.01)$ and, as expected, pluriparous cows produced 1623 more milk in 305 days than primiparous cows. $2 \mathrm{x}$ cows reached peak milk yield later $(p<0.01)$ in lactation $(79 \mathrm{~d})$ than $3 \mathrm{x}$ cows $(64 \mathrm{~d})$. There was a parity by days to peak milk yield interaction $(p<0.01)$. The mean days to milk yield was higher in $2 \mathrm{x}$ primiparous cows than pluriparous cows; the opposite occurred with three times a day milking.

Peak milk yield was higher in $2 \mathrm{x}$ cows $(\phi<0.02)$ than $3 \mathrm{x}$ cows, likewise multiparous cows presented higher $(p<0.01)$ milk yield at peak than primiparous cows. 3x cows produced 470 more $(\phi<0.05) \mathrm{kg}$ of milk from 305 DIM to the end of lactation than $2 \mathrm{x}$ cows. There was a significant interaction between parity and frequency of milking for milk yield produced from 305 DIM to the end of lactation. There was a reduction in this trait in $3 x$ primiparous cows compared to $2 x$ primiparous cows; the opposite occurred with multiparous cows. Across parities, total milk yield was $1091 \mathrm{~kg}$ higher $(p<0.01)$ in $3 \mathrm{x}$ cows than $2 \mathrm{x}$ cows. There was a parity by total milk yield interaction $(p<0.01)$. The mean total milk yield was higher in $2 \mathrm{x}$ primiparous cows than pluriparous cows; the opposite occurred with $3 \mathrm{x}$ cows.

Across parity, persistency during 305-d lactations was significantly improved $(\phi<0.01)$ by milking the cows more frequently. However, when the analysis was extended to the whole lactation $2 \mathrm{x}$ cows presented a higher $(p<0.05)$ persistence than $3 \mathrm{x}$ cows. Across frequency of milking, primiparous cows presented a higher persistence than multiparous cows. The association between DIM and total milk yield is presented in Fig. 2. For both primiparous and multiparous cows, cows with lactations $>1000$ days had a negligible rate of increase in milk yield after this stage of lactation.

Reproductive data are presented in Table 2. First service conception rate was affected $(p<0.01)$ by frequency of milking being 7 percentage points lower in $3 x$ compared to $2 \mathrm{x}$ cows. Conception rate to all services did not differ between $2 \mathrm{x}$ or $3 \mathrm{x}$ cows and $3 \mathrm{x}$ cows required on average one more service $(p<0.01)$ to become pregnant than $2 \mathrm{x}$ cows. 
Table 1: Effect of milking two compared to three times a day on different milk production variables in primiparous and multiparous subfertile Holstein cows undergoing extended lactations ( $\geq 600$ days) in a hot environment

\begin{tabular}{|c|c|c|c|c|c|c|c|c|}
\hline \multirow[t]{2}{*}{ Milk variables } & \multicolumn{2}{|c|}{$2 x$} & \multicolumn{2}{|c|}{$3 x$} & \multirow[t]{2}{*}{ SEM } & \multirow[t]{2}{*}{ MF effect } & \multirow[t]{2}{*}{ Lact effect } & \multirow[t]{2}{*}{ MF $x$ Lact } \\
\hline & $\begin{array}{c}1^{\text {st }} \text { lact } \\
n=(132)\end{array}$ & $\begin{array}{l}\geq 2 \text { lact } \\
n=(82)\end{array}$ & $\begin{array}{c}1^{\text {st }} \text { lact } \\
n=(154)\end{array}$ & $\begin{array}{l}\geq 2 \text { lact } \\
n=(91)\end{array}$ & & & & \\
\hline $\begin{array}{l}\text { Lactation length, } \\
\text { days }\end{array}$ & 650 & 631 & 696 & 685 & 99 & $<.0001$ & 0.1107 & 0.6731 \\
\hline 305-d milk yield, kg & 10006 & 11600 & 10619 & 12284 & 995 & $<.0001$ & $<.0001$ & 0.7093 \\
\hline $\begin{array}{l}\text { Days to peak milk } \\
\text { yield }\end{array}$ & 79 & 75 & 63 & 66 & 15 & $<.0001$ & 0.4722 & 0.0022 \\
\hline Peak milk yield, kg & 46 & 53 & 47 & 55 & 8 & 0.0244 & $<.0001$ & 0.5863 \\
\hline $\begin{array}{l}\text { Milk yield } 305 \\
\text { to } \geq 600 \mathrm{~d}, \mathrm{~kg}\end{array}$ & 9262 & 7310 & 9177 & 8657 & 3290 & 0.0475 & 0.0001 & 0.0246 \\
\hline Total milk yield, kg & 19269 & 18910 & 19796 & 20942 & 3250 & $<.0001$ & 0.2103 & 0.0169 \\
\hline $\begin{array}{l}\text { Milk/day in } 305 \\
\text { d, kg }\end{array}$ & 32.8 & 38.0 & 34.8 & 40.2 & 3.2 & $<.0001$ & $<.0001$ & 0.7093 \\
\hline $\begin{array}{l}\text { Milk/day whole } \\
\text { lactation, kg }\end{array}$ & 29.6 & 30.0 & 28.5 & 30.7 & 2.4 & 0.3368 & $<.0001$ & 0.0003 \\
\hline $\begin{array}{l}\text { Milk/day from } 600 \mathrm{~d} \\
\text { to end, } \mathrm{kg}\end{array}$ & 26.5 & 22.4 & 23.4 & 22.5 & 4.6 & $<.0001$ & $<.0001$ & 0.0003 \\
\hline $\begin{array}{l}\text { Persistence } 305-d \\
\text { milk yield (\%) }\end{array}$ & 72.5 & 72.4 & 75.9 & 75.0 & 11.9 & 0.0094 & 0.6389 & 0.6973 \\
\hline $\begin{array}{l}\text { Persistence whole } \\
\text { lactation (\%) }\end{array}$ & 65.4 & 57.2 & 62.2 & 56.6 & 9.0 & 0.0363 & $<.0001$ & 0.1524 \\
\hline
\end{tabular}

$\mathrm{SEM}=$ standard error of the mean; MF=milking frequency; Lact= lactation; $2 \mathrm{x}=$ two times daily milking; $3 \mathrm{x}=$ three times daily milking.

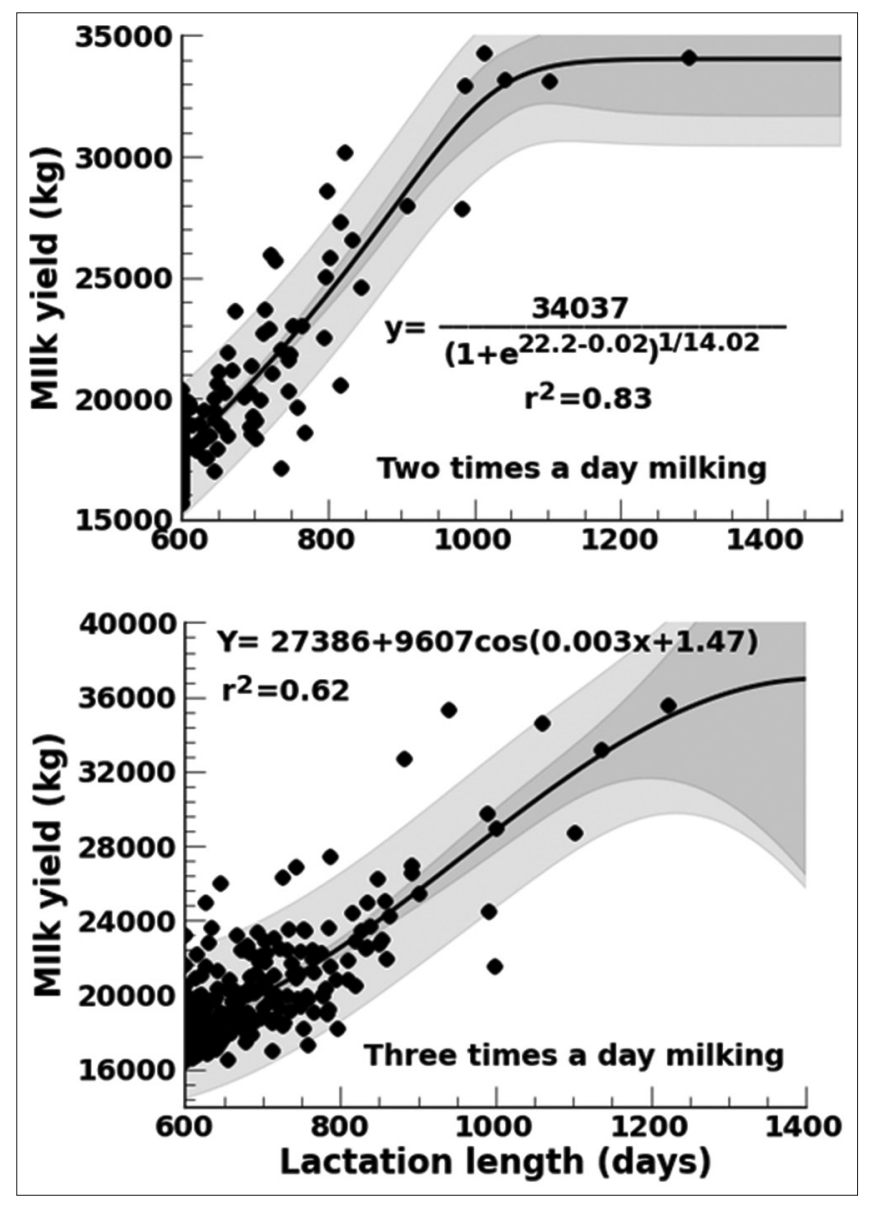

Fig 2. Association between total milk yield and lactation length in highyielding Holstein cows undergoing lactations $\geq 600$ days and subjected to prolonged thermal stress.
Table 2: Influence of milking two compared to three times a day on different reproductive variables in subfertile Holstein cows undergoing extended lactations ( $\geq 600$ days) in a hot environment

\begin{tabular}{lcc}
\hline Reproductive variable & $\mathbf{2 x}$ & $\mathbf{3 x}$ \\
\hline $\begin{array}{l}\text { Conception rate at first } \\
\text { service }\end{array}$ & $19.2(41 / 214)^{\mathrm{a}}$ & $12.2(30 / 245)^{\mathrm{b}}$ \\
$\begin{array}{l}\text { Conception rate to all } \\
\text { services }\end{array}$ & $53.3(114 / 214)$ & $49.8(122 / 245)$ \\
$\begin{array}{l}\text { Services per } \\
\text { conception (pregnant cows) }\end{array}$ & $4.8 \pm 3.4^{\mathrm{a}}$ & $5.9 \pm 3.7^{\mathrm{b}}$ \\
\hline
\end{tabular}

$2 x=$ two times daily milking; $3 x=$ three times daily milking. ${ }^{\text {ab Means in the }}$ same raw do not shearing the same superscript differ $p<0.01$ )

\section{DISCUSSION}

Even though this was not a randomized control trial, the present study was deemed adequate methodologically because of the large number of data used and because it included an appropriate cohort that provided good estimates of treatment effect. Across parity, lactation length was significantly longer for $3 \mathrm{x}$ than $2 \mathrm{x}$ cows, and for both groups, mean lactation length was 669 days. This response seems to be related to poorer reproductive performance in $3 \mathrm{x}$ than $2 \mathrm{x}$ cows. Herds milked $3 \mathrm{x}$ in southern USA tended to have more days open, longer calving intervals, and greater services per pregnancy than herds milked 2x (Smith et al., 2002). In the present study, 3x cows required more SC than $2 \mathrm{x}$ cows, which led to greater calving to conception interval and consequently to longer lactations. Lactation lengths $\geq 600$ days have been also reached in Holstein-Friesian cows with two times a day milking on 
pasture-based production systems (Kolver et al., 2007; Grainger et al., 2009). Thus, clearly, three times a day milking is not an essential condition to achieve lactation of over 20 months in high-yielding Holstein cows.

In this study, parity did not influence lactation length, which is not in line with previous studies indicating that cow's age (lactation number) is a strong factor influencing the proportion of extended lactations (Sawa and Bogucki, 2009), seemly due to a higher persistence observed in primiparous compared to pluriparous cows (Miller et al., 2006). However, in line with previous studies (López et al., 2015), primiparous cows presented a higher persistence than multiparous cows, which indicates that lactation length was primarily influenced by earlier pregnancy of cows rather than parity.

Peak milk yield was higher in $3 \mathrm{x}$ than $2 \mathrm{x}$ cows. The increase in milk production from calving to peak milk yield is due to increased secretory activity per secretory cell rather than to accretion of supplementary epithelial cells (Capuco et al., 2003). Data of the present study then suggest that increasing frequency of milking increased secretory activity of epithelial cells which resulted in greater milk yield at peak lactation.

There is plenty of evidence to prove that high-yielding cows milked more frequently than twice-daily significantly produce higher yields (Smith et al., 2002; Österman and Bertilsson, 2003; Stelwagen et al., 2013). Results of the present study reaffirm this fact because $3 \mathrm{x}$ milking increased 305-d milk yield for pluriparous cows and cows in first lactation by $5.9 \%$ and $6.1 \%$ compared with $2 \mathrm{x}$ milking. Field studies evaluating $3 \mathrm{x}$ milking reported greater response of milk production per lactation (12-15\%; Smith et al., 2002; Vijayakumar et al., 2017) than that in the present study. Undefined management factors other than milk frequency may have accounted for some of the reduced milk yield differences in this study.

When considering total milk yield, $3 x$ cows produced more milk than $2 \mathrm{x}$ cows, which is in agreement with Sorensen et al., (2008), but by looking at the milk/day during the whole lactation, there were no differences between $2 \mathrm{x}$ and $3 x$ cows. This implies that both groups of cows had a low rate of milk decline, which led to a high persistence well beyond 600 days of lactation. Lactation persistence not only is due to the cow's ability to maintain milk secretory activity after peak of lactation but is also a consequence of the postpartum development of the mammary gland and tissue remodeling as milk yield decays at the end of lactation (Dessauge et al., 2011). Yet the proliferative rate of mammary cells is sufficient to replace most mammary epithelial cells by the end of lactation (Capuco et al., 2003). Regulation of mammary cell renewal provides a key to increasing persistency and various factors influence lactation persistency, particularly hormonal changes (Yart et al., 2013, 2014) and cell regulation mechanisms leading to apoptosis (Sorensen et al., 2006; Norgaard et al., 2008).

Milk yield of cows with $\geq 600$ DIM was remarkably high in both $2 \mathrm{x}$ and $3 \mathrm{x}$ cows, which allowed some cows to extend their lactations to nearly 1000 days with a mean total milk yield of $19714 \mathrm{~kg}$. This milk yield is about 20\% higher than milk yield reached in previous studies with well-fed cows with lactations ranging from 486 to 670 days (Van Amburgh et al., 1997; Grainger et al., 2009). The fact that milk yield plateaued at around 1000 DIM supports previous research indicating that, after 300 DIM in cows undergoing extended lactations, cows progressively partition energy toward tissue gain rather than milk production (Williams et al., 2013; Marett et al., 2017, 2018). Also, more nitrogen is partitioned to urine and less to milk and feces at the final stages of prolonged lactations (Moate et al., 2017). Hence, it seems that it exists a decreased priority of lactation during the last phase of the extended lactation.

Regardless of frequency of milking, the overall first service pregnancy rate was $15 \%$, which is similar to previous studies of farms that used similar reproductive management strategies and cows undergoing prolonged heat stress (Mellado et al., 2016). The low first-service conception rate denoted a series of obstacles for a successful pregnancy early in lactation which led to prolonged calving to conception interval and consequently to extended lactations. $3 x$ cows had a reduced probability of first service conception rate as compared to $2 \mathrm{x}$ cows. Other researchers (Smith et al., 2002; Patton et al., 2006; García-Ispierto et al., 2007) have found a relationship between milking frequency and reduced fertility. CR to first service and SC for 3x animals were poorer compared with $2 \mathrm{x}$ cows. The lower reproductive performance of $3 \mathrm{x}$ cows may be related to the less negative daily energy balance for $2 \mathrm{x}$ compared to $3 \mathrm{x}$ cows (Patton et al., 2006). Additionally, 3x cows lost more weight over lactation than $2 \mathrm{x}$ cows indicating that $3 \mathrm{x}$ cows were in negative energy balance for a greater proportion of their lactation (Andersen et al., 2003).

Regardless of milking frequency, only about half the cows become pregnant to all services. This low level of fertility in high-yielding Holstein cows has been previously reported for dairy herds in this region (Mellado et al., 2013). SC for pregnant cows were lower for $2 \mathrm{x}$ than $3 \mathrm{x}$ cows, but both groups required about 5 inseminations to become pregnant. This high number of insemination per pregnancy was due to the chronic heat stress experienced by these cows. The strong deleterious effect of heat on SC is not only manifested on the day of $\mathrm{AI}$ but in subsequent services (Mellado et al., 2013). 


\section{CONCLUSIONS}

Although three times a day milking instead of twice a day resulted in an increase in total milk yield during the entire lactation, this study found that profitable extended lactations (about $30 \mathrm{~kg}$ milk/day for over 600 days) can be achieved with twice a day milking. Therefore, three times a day milking is not essential for maintaining a high milk yield persistency and milk production in high-yielding Holstein cows undergoing extended lactations under intensive production systems. These results also indicate that three times a day milking had negative effects on first service conception rate and services per pregnancy, two well-known contributors to extended lactations. However, extended lactations could be a part of a management strategy rather than the result of the inability of cows to become pregnant.

\section{ACKNOWLEDGMENTS}

This research did not receive any specific funding

\section{Conflict of interest}

The authors declare that no conflict of interest could be perceived as prejudicing the impartiality of the research reported.

\section{Authors' contributions}

Conceived the experiment: J. Mellado, and M. Mellado. Performed field trial: F.G. Véliz, J.E. García and H.L. Gutierrez. Performed statistical analysis and interpretation of results: A. de Santiago and M. Mellado. Wrote the manuscript: M. Mellado. All authors read and approved the manuscript.

\section{REFERENCES}

Andersen, J. B., N. C. Friggens, K. Sejrsen, M. T. Sørensen, L. Munksgaard and K. L. Ingvartsen. 2003. The effects of low vs. high concentrate level in the diet on performance in cows milked two or three times daily in early lactation. Livest. Prod. Sci. 81: 119-128.

Auldist, M. J., G. O’Brien, D. Cole, K. L. MacMillan and C. Grainger. 2007. Effects of varying lactation length on milk production capacity of cows in pasture-based dairying systems. J. Dairy Sci. 90: 3234-3241.

Berry, D., N. C. Friggens, M. Lucy and J. R. Roche. 2016. Milk production and fertility in cattle. Ann. Rev. Anim. Biosci. 41: 269-290.

Capuco, A., S. E. Ellis, S. A. Hale, E. Long, R. A. Erdman, X. Zhao and M. J. Paape. 2003. Lactation persistency: Insights from mammary cell proliferation studies. J. Anim. Sci. 81: 18-31.

Dessauge, F., V. Lollivier, L. Finot, S. Wiart, E. Cutullic, C. Disenhaus, S. Barbey and M. Boutinaud. 2011. Effects of nutrient restriction on mammary cell turnover in lactating dairy cows. J. Dairy Sci. 94: 4623-4635.
García-Ispierto, I., F. López-Gatius, P. Santolaria, J. L. Yániz, C. Nogareda and M. López-Béjar. 2007. Factors affecting the fertility of high producing dairy herds in northeastern Spain. Theriogenology. 67: 632-638.

Grainger, C., M. J. Auldist, G. O'Brien, K. L. MacMillan and C. Culley. 2009. Effect of type of diet and energy intake on milk production of Holstein-Friesian cows with extended lactations. J. Dairy Sci. 92: 1479-1492.

Hernandez, L. L., J. L. Collier A. J. Vomachka R. J. Collier and N. D. Horseman. 2011. Suppression of lactation and acceleration of involution in the bovine mammary gland by a selective serotonin reuptake inhibitor. J. Endocrinol. 209: 45-54.

Kolver, E. S., J. R. Roche, C. R. Burke, J. K. Kay and W. Aspin. 2007. Extending lactation in pasture-based dairy cows: Genotype and diet effect on milk and reproduction. J. Dairy Sci. 90: 5518-5530.

Lehmann, J. O., L. Mogensen and T. Kristensen. 2017. Early lactation production, health, and welfare characteristics of cows selected for extended lactation. J. Dairy Sci. 100: 1487-1501.

Lehmann, J. O., L. Mogensen and T. Kristensen. 2019. Extended lactations in dairy production: Economic, productivity and climatic impact at herd, farm and sector level. Livest. Sci. 220 100-110.

López, S., J. France, N. E. Odongo, R. A. McBride, E. Kebreab, O. Alzahal, B. W. McBride and J. Dijkstra. 2015. On the analysis of Canadian Holstein dairy cow lactation curves using standard growth functions. J. Dairy Sci. 98: 2701-2712.

Marett, L. C., M. J. Auldist, P. J. Moate, W. J. Wales, L. K. Macmillan, F. R. Dunshea and B. J. Leury. 2015. Response of plasma glucose, insulin, and non-esterified fatty acids to intravenous glucose tolerance tests in dairy cows during a 670-day lactation. J. Dairy Sci. 98: 179-189.

Marett, L. C., M. J. Auldist, W. J. Wales, K. L. MacMillan, F. R. Dunshea and B. J. Leury. 2017. Responses of plasma glucose and non-esterified fatty acids to intravenous insulin tolerance tests in dairy cows during a 670-day lactation. J. Dairy Sci. 100: 3272-3281.

Marett, L. C., M. J. Auldist, W. J. Wales, K. L. MacMillan, F. R. Dunshea and B. J. Leury. 2018. Plasma glucose and non-esterified fatty acids response to epinephrine challenges in dairy cows during a 670-d lactation. J. Dairy Sci. 101: 3501-3513.

McNamara, S., J. J. Murphy, F. P. O'Mara, M. Rath and J. F. Mee. 2008. Effect of milking frequency in early lactation on energy metabolism, milk production and reproductive performance of dairy cows. Livest. Sci. 117: 70-78.

Mellado, M., J. M. Flores, A. de Santiago, F. G. Veliz, U. Macías-Cruz, L. Avendaño-Reyes and J. E. García. 2016. Extended lactation in high-yielding Holstein cows: Characterization of milk yield and risk factors for lactations $>450$ days. Livest. Sci. 189: 50-55.

Mellado, M., E. Sepulveda, C. A. Meza-Herrera, F. G. Véliz, J. R. Arevalo, J. Mellado and A. de Santiago. 2013. Effects of heat stress on reproductive efficiency of high yielding Holstein cows in a hot-arid environment. Rev. Colomb. Cienc. Pecu. 26: 193-200.

Miller, N., L. Delbecchi, D. Petitclerc, G. F. Wagner, B. G. Talbot and A. Lacasse. 2006. Effect of stage of lactation and parity on mammary gland cell renewal. J. Dairy Sci. 89: 4669-4677.

Moate, J., S. R. O. Williams, M. C. Hannah, L. C. Marett, M. J. Auldist, J. L. Jacobs and W. J. Wales. 2017. Partitioning of dietary nitrogen in response to feeding cereal grain supplements to dairy cows during four periods of an extended lactation. Anim. Prod. Sci. 57: 1520-1524.

Murney, R., K. Stelwagen, T. T. Wheeler, J. K. Margerison and K. Singh. 2015. The effects of milking frequency in early lactation on milk yield, mammary cell turnover, and secretory activity in 
grazing dairy cows. J. Dairy Sci. 98: 305-311.

Norgaard, J., K. Theil, M. T. Sorensen and K. Sejrsen. 2008. Cellular mechanisms in regulating mammary cell turnover during lactation and dry period in dairy cows. J. Dairy Sci. 91: 2319-2327.

NRC-National Research Council. 2001. Nutrient Requirements of Dairy Cattle. $7^{\text {th }}$ ed. National Academic Press, Washington, DC.

Österman, S. and J. Bertilsson. 2003. Extended calving interval in combination with milking two or three times per day: Effects on milk production and milk composition. Livest. Prod. Sci. 82: 139-149.

Patton, J., D. A. Kenny, J. F. Mee, F. O'Mara, D. C. Wathes, M. Cook and J. J. Murphy. 2006. Effect of milking frequency and diet on milk production, energy balance, and reproduction in dairy cows. J. Dairy Sci. 89: 1478-1487.

Rajala-Schultz, J., N. Gott, K. L. Proudfoot and G. M. Schuenemann. 2018. Effect of milk cessation method at dry-off on behavioral activity of dairy cows. J. Dairy Sci. 101: 3261-3270.

Rodríguez-Godina, I. J., J. E. García, J. Mellado, L. Morales-Cruz, V. Contreras, U. Macías-Cruz, L. Avendaño-Reyes and M. Mellado. 2021. Permanence time in the herd and milk production of Holstein cows with up to five successive extended lactations. Trop. Anim. Health Prod. 53: 141-248.

Sawa, A. and M. Bogucki. 2009. Effect of extended lactations on cow milk and reproductive performance. Arch. Tierzucht. 52: 219-229.

Sehested, J., C. Gaillard, J. O. Lehmann, G. M. Maciel, M. Vestergaard, M. R. Weisbjerg, L. Mogensen, L. B. Larsen, N. A. Poulsen and T. Kristensen. 2019. Review: Extended lactation in dairy cattle. Animal. 13: 65-74.

Smith, J. W., L. O. Ely, W. M. Graves and W. D. Gilson. 2002. Effect of milking frequency on DHI performance measures. J. Dairy Sci. 85: 3526-3533.

Sorensen, A., D. D. Muir and C. H. Knight. 2008. Extended lactation in dairy cows: Effects of milking frequency, calving season and nutrition on lactation persistency and milk quality. J. Dairy Res. 75: 90-97.
Sorensen, M. T., J. Norgaard, K. Theil, M. Vestergaard and K. Sejrsen. 2006. Cell turnover and activity in mammary tissue during lactation and the dry period in dairy cows. J. Dairy Sci. 89: 4632-4639.

Stelwagen, K., C. C. Phyn, S. R. Davis, J. Guinard-Flament, D. Pomiès, J. R. Roche and J. K. Kay. 2013. Invited review: Reduced milking frequency: Milk production and management implications. J. Dairy Sci. 96: 3401-3413.

van Amburgh, M. E., D. M. Galton, D. E. Bauman and R. W. Everett. 1997. Management and economics of extended calving intervals with use of bovine somatotropin. Livest. Prod. Sci. 50: 15-28.

Vijayakumar, M., J. H. Park, K. S. Ki, D. H. Lim, S. B. Kim, S. M Park, H. Y. Jeong, B. Y. Park and T. I. Kim. 2017. The effect of lactation number, stage, length, and milking frequency on milk yield in Korean Holstein dairy cows using automatic milking system. Asian Aust. J. Anim. Sci. 30: 1093-1098.

Wall, E. H. and T. B. McFadden. 2012. A local affair: How the mammary gland adapts to changes in milking frequency. J. Anim. Sci. 90: 1695-1707.

Walsh, S. W., E. J. Williams and A. C. Evans. 2011. A review of the causes of poor fertility in high milk producing dairy cows. Anim. Reprod. Sci. 123: 127-138.

Weaver, S. R. and L. L. Hernandez. 2016. Autocrine-paracrine regulation of the mammary gland. J. Dairy Sci. 99: 842-853.

Williams, S. R. O., T. Clarke, M. C. Hannah, L. C. Marett, J. Moate, M. J. Auldist and W. J. Wales. 2013. Energy partitioning in herbage-fed dairy cows offered supplementary grain during an extended lactation. J. Dairy Sci. 96: 484-494.

Yart, L., L. Finot, V. Lollivier and F. Dessauge. 2013. Oestradiol enhances apoptosis in bovine mammary epithelial cells in vitro. J. Dairy Res. 80: 113-121.

Yart, L., V. Lollivier, G. Marnet and F. Dessauge. 2014. Role of ovarian secretions in mammary gland development and function in ruminants. Animal. 8: 72-85. 